THE SHIP "VANGUARD."

[YOTR FROM MR. R. DOCGLAS, R.X.]

To the Editor of THE LANCET.

Sir,--Having observed a paragraph in Tн L LANCET of the 19 th instant," signed "F. J. B.," reflecting on the conduct of the surgeon, late of H.M.S. Fanguard, connected with a circumstance hasing reference to "gagging a drunken, noisy man" on board of that ship, I have to request you will contradict the statenent of "F. J. B."-viz., "that the surgeon kept out of the way, and would not interfere," \&c.

I beg to assure you, that when the assistant-surgeon reported to me the occurrence, I immediately went on the quarter-deck, remonstrated with the commanding officer, attended to the gagged man myself, and, at my suggestion, instead of that punishment being prolonged, the man was placed in confinement below directly.

As neither the captain nor the commander was on board at the time, it was at the option of the assistant-surgeon, the following morning, if he had felt himself or his professiona dignity degraded by what he conceived to be an usurped authority exercised over him by the commanding officer, to have preferred a complaint, through me, to either of the above-mentioned superior officers, but this he declined to do.

The dignity and honour of the medical profession in the naval service are as equally dear to me as to your correspondent "F.J. B.;" and as a medical man's duties on board of ship are exereised to relieve suffering humanity, whether under disease or punishment, I do not consider that his superintendence at the latter, in order to counteract any undue severity in its infliction, can be regarded as derogatory to his profession.

$$
\begin{gathered}
\text { I am, Sir, your obedient servant, } \\
\text { Plymouth, Jannary 24, 1850. DoogIAs, Surgeon, R.N., } \\
\text { Member of the Royal College } \\
\text { of Surgeon, Lond , and } \\
\text { late Surzeon of H.M.S. } \\
\text { Vangutrd. }
\end{gathered}
$$

\section{THE SPECULUM IN CASES OF LABOUR.}

\section{To the Editor of THe LANCET.}

SrR,-From having used the speculum vaginæe for a sufficient period to appreciate its value in uteriue diseases, $I$ am led to suggest the propriety of its use during parturition, when doubt exists in the mind of the practitioner as to the presentation. Should you consider this worthy a space in your valuable journal, you will oblige

Kentish Town, Jan. 1850 .

Your obedient servant,

F. W. A. RAWIINS, M.D.

\section{FACULTY OF PHYSICIANS AND SURGEONS OF GLASGOW.}

\section{To the Elitor of The Lancet.}

Sir,-Like your correspondent of the 19th December, I have with surprise heard of the intimation put forth by the Glasgow faculty of physicians and surgeons to which he alludes.

At a juncture so critical to medical interests as the present, when there is the greatest requirement for the exercise of a conciliatory temper amongst the various licensing departments, and for the diffusion of good feeling amongst the profession at large, it seems quite preposterous that a public body, which, without doubt, is the most unnecessary of all, should thus, at the eleventh hour, come forward and talk of applying for "alteration and amendment of their charter." +

The privileges \&c. possessed by virtue of said charter being purposely very limited, the licence for practice which the Glasgow faculty is empowered to grant has a legal recognition within only a small portion of the west of Scotland (four conterminous counties), and is of conrse in this respect, as well as otherwise, insufficient to compete with the diploma of either of the three British Royal Colleges of Surgeons. The unquestioned respectability and efficieney of the Glasgow faculty as a professional body have nothing to do with the matter at issue, and cannot be admitted as forming a special plea for

* No. III of THE LA NCET for 1850, p. 100.

$\dagger$ In addition, " a deputation from the Faculty of Phy sicians and Surgeons of Glasgow, consisting of Drs. Watson, \&c. \&c., waited on the Town Council of Gapgow, on Thursday last (17th inst.), with a memorial, craving assist ance and co-operation of the Council, \&c., and support to a measure proposed to be introduced into Parliament for the purpose of securing to the Glasgow Faculty additional privileges to those which they hold under their present charter. The deputation having withdrawn, the Lord Provost to Paftiament in terms of the memorial." - Glusgow Saturday Post, Jan. 19. the legislative bestowal of "additional privileges," \&c. There exists no medical body in any other provincial district of Great Britain similarly charter-gifted with the faculty of Glasgow, nor, as already stated, is there the most remote necessity for its existence as a licensing body. It seems really never to have been well enough considered on this point, that, the Royal College of Surgeons of England being quite suffcient as a surgical diploma-granting board for all England, and the Royal College of Surgeons of Ireland being in the same manner equally sufficient for the whole of Ireland, one Royal College of Surgeons is, beyond doubt, all that is (or has ever been) needed for Scotland; and as the capitals of London and Dublin are the seats of the respective colleges for England and Ireland, so ought Edinburgh, as the northern metropolis, to contain the Royal College of Surgeons of Scotland.

The contemplated measure of reform, of which you, Sir, have ever proved the stanch and able advocate, is not contrived for the purpose of wresting from any one medical body what is to flatter or aggrandize any other medical body, but is calculated to raise the great medical faculty of the empire to a merited condition of dignity never before attained.

Sincerely hoping that the Glasgow faculty may, on due consideration, be induced, not only to suppress their present apparent opposition, but to act heart and hand in unison with all who are endeavouring to compass the devoutly-wished consummation of our professional wishes, and at the same time leave "the wisdom of many councillors" the decision of questions relating particularly to self,

January 24, 1850 .

I am, your most obedient servant, Medices.

\section{SUPERSTITION IN RHYME.}

To the Editor of Tre LaNcer.

Sin,- You will probably deem it necessary to make some comment upon a very singular inquest, reported in the daily papers, relative to the death of an unfortnnate child through the mal-treatment of an old woman, who undertook to "charm" away a burn.

The coroner and jury appear, naturally enough, to have given utterance to their feelings in very strong language, but they do not appear to have been aware of what I am desirous of bringing under your especial notice-viz., the singular fact that " the charm" is no invention of this miserable, ignorant, old woman, but actually given (along with some others in Latin, if my memory serves me, for I have not the volume at hand) in the celebrated "Diary of Samuel Pepys," beginning "Two angels came out of the west."

By Pepys inserting them in his "Diary," it would seem that, even in his time, such jingling absurdities were becoming ont of date (descending, most likely, from monkish times, when a belief in witcheraft and conjuring appears to have been oddly mixed up with a perverted religious feeling;) and it convers, I think, no slight reproach upon Englishmen of the nineteenth century, that an observer in the seventeenth so regarded them.

Surely, Sir, such an instance of disgusting superstition will be sufficient to rouse every thinking man in the kingdom to the imperative necessity for an educational antidote.

$$
\text { I am, Sir, your obedient servant, }
$$
Bucklersbury, January, 1850 .
B. B. Orridat.

\section{TAX ON MEDTCAL ASSISTANTS. To the Editor of THE LANCET.}

Sir,- - You will confer a great favour on medical assistants, by informing the profession trat the Medical Protection Society, who, I suppose, propose to supply medical men with assistants free of charge, at the same time charge to the assistants two and a half per cent. on the first year's salary, to be paid in advance. Thus, if $\mathrm{I}$ agree to go to a situation at $\mathfrak{£} 30$ per year, I must give them $15 s$. immediately on my entering on the situation-it matters not if I only stay three months. At the British Medical Agency they charge five per cent.- the office is in Regent-street. Mr. Orridge, Bucklershury, and Mr. Jaeolson, Queen-street, Cheapside, each charge $3 s .6 d$. to assistants, and the same sum to employers. This, I think, is reasonable enough. I an sure medieal gentlemen do not wish to saddle their assistants with a tax of $15 s$. or $30 s$, which they certainly will, if their orders for assistants are sent to two of the forementioned places.

Jamuary, 1530.

I am, Sir, your obedient servant, 